\title{
Enhancing performance of grid-connected photovoltaic systems based on three-phase five-level cascaded inverter
}

\author{
Marwan E. Ahmad', Ali. H. Numan'2, Dhari Y. Mahmood ${ }^{3}$ \\ ${ }^{1,3}$ Departement of Electrical Engineering, University of Technology, Baghdad, Iraq \\ ${ }^{2}$ Departement of Electromechanical Engineering, University of Technology, Baghdad, Iraq
}

\begin{tabular}{l} 
Article Info \\
Article history: \\
Received Jun 10, 2021 \\
Revised Sep 2, 2021 \\
Accepted Sep 9, 2021 \\
\hline Keywords: \\
Cascaded H-bridge inverters \\
Grid-connected PV systems \\
Photovoltaic panels mismatch \\
Maximum power point tracking \\
Multilevel modulations \\
compensation
\end{tabular}

Article Info

Article history:

Received Jun 10, 2021

Revised Sep 2, 2021

Accepted Sep 9, 2021

\section{Keywords}

Cascaded H-bridge inverters Grid-connected PV systems Photovoltaic panels mismatch Multilevel modulations compensation

\begin{abstract}
Multilevel inverters play an important role in power converters due to their good advantages. The cascaded H-bridge inverter is one of the most prominent and most suitable multilevel inverters in PV systems. Each Hbridge has a separate photovoltaic (PV) array as an independent direct current (DC) source. This paper introduces a three-phase cascaded H-bridge inverter with five levels connected to the grid to improve the performance and efficiency of the photovoltaic system. In the proposed system, each PV group has MPPT to extract the maximum power point from the PV group at certain irradiation and temperature and also to mitigate the mismatch that causes in the imbalance transmitted power from inverter to the main grid. The proposed control scheme with modulation compensation was used, and the system was simulated in MATLAB/Simulink with two different scenarios. The simulation results demonstrate the effectiveness of the proposed connection in minimizing the total harmonic distortion (THD) to acceptable limit, low overshoot, and fast-tracking to the desired value.
\end{abstract}

This is an open access article under the CC BY-SA license.

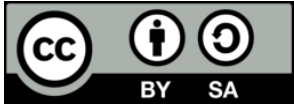

Corresponding Author:

Marwan saded Ahmed

Departement of Electrical Engineering

University of Technology

Baghdad, Iraq

Email: Marwanesd448@gmail.com

\section{INTRODUCTION}

Many countries nowadays rely heavily on wind energy and solar panel energy as a source of renewable energy (RES), especially with the spread and development of technology, being more reliable and sustainable to form a microgrid integrated with the traditional grid and solve the problem of increasing energy demand and reducing dependence on fuel fossil and environmental conservation [1], [2]. Energy management and the conversion of (RES) into electricity and its storage requires the use of electronic devices as power converter systems and must be ideal in configuration and size and meet the requirements for optimum operation of microgrid in terms of high efficiency, performance, reliability, stability, low cost, protection, and effective energy regulation [3], [4]. One of the most important electronic power converters, which is an inverter. An inverter can be defined as an electronic device that converts DC power into alternating current (AC) power while maintaining the output voltage and frequency [4]. Inverters are divided into two types: the first type is a two-level inverter and the second is a multilevel inverter with three levels or more. Because of the high switching losses, high switching frequency, harmonic distortion, and other problems in the two-level inverter as it does not prefer to be used in high and medium voltage transformations, the engineers of electronic power and modern technology have tended to pay attention to and use the multilevel inverter because of its many advantages and high capacity to deal with medium and high energy with its positive contribution in the field of 
renewable energy and electronic capacity. Multilevel inverters are classified into three classes [5]-[7]; (i) flying capacitor multilevel inverter, (ii) cascaded H-Bridge multilevel inverter, and (iii) diode clamped multilevel inverter.

There are many researchers are used the multilevel inverter with PV system in grid-connected mode as [4], [8], [9]. This paper presents a five-level H-bridge inverter topology that is cascaded and connected to the utility grid using solar panels as a DC source. The mismatch of the photovoltaic panel is one of the most serious issues with this system, as each PV module gives its power (MPP) owing to changes in irradiance, temperature. As a result, the power provided to the inverter is unbalanced, resulting in an imbalance in grid current injection. In order to solve this issue, this proposed cascade H-bridge with a separate PV group is used [8], [10].

\section{SYSTEM DESCRIPTION}

The proposed configuration is composed of six PV groups and each group supplies H-bridge with DC voltage $218.5 \mathrm{~V}$, DC-DC converter with MPPT to extract maximum power any certain weather condition, five-level cascaded $\mathrm{H}$ bridge, LC filter, and coupling transformer for interface the proposed system with the main grid. The conception and details of each component in Figure 1 are explained in the bellow sections is being as,

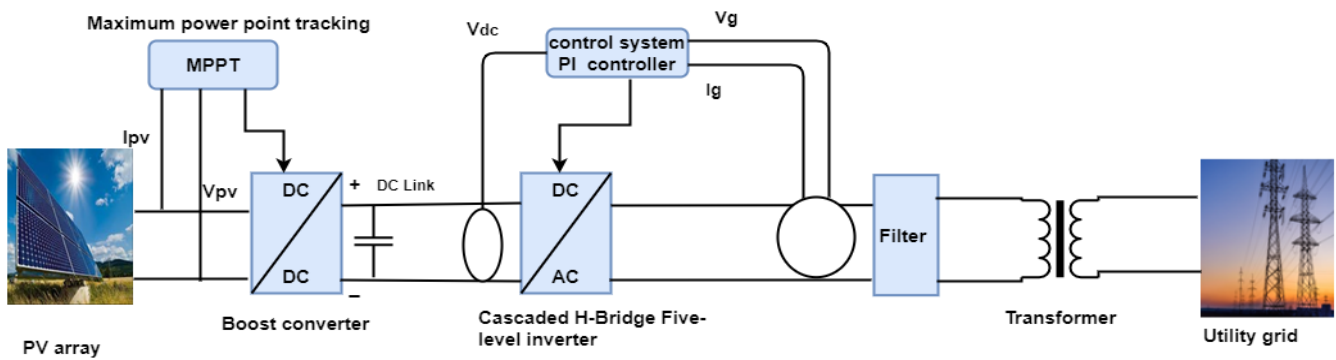

Figure 1. Components of a proposed PV system

\subsection{PV array}

The solar cell is the basic unit for forming PV panels. A solar cell can be defined as a semiconductor material that converts solar radiation into electrical energy and the solar cell consists of a thin layer of a semiconductor material that is fabricated on a PN junction such as silicon, cadmium telluride, gallium, and arsenide, its operational properties are similar to that of a diode $\mathrm{p}-\mathrm{n}$ as it relies on solar radiation and surface temperature to generate electrical current. A photovoltaic cell can generate almost a voltage 0.5 to $0.8 \mathrm{~V}$ depending on the advanced technology and type of semiconductor material used.

The voltage generated by a single solar cell is insufficient for the applications, so the solar cells are connected in one frame in series and parallel to their component called the solar panel. The equivalent circuit of a solar cell can consist of a single or double diode, and a single diode is more efficient and easier to analyze. Figure 2 shows the equivalent circuit of a solar cell with a single diode [9], [11]. The relationship between output voltage (VPV) and output current (IPV) in the equivalent circuit of a single diode can be analyzed mathematically is being as [12].

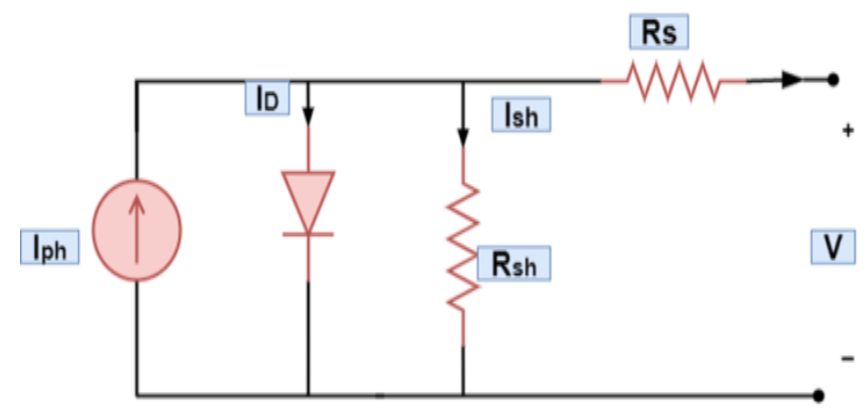

Figure 2. Equivalent circuit of a single diode solar cell 


$$
I P V=I p h-I D-I s h
$$

Where:

- IPV: Current of PV cell,

- A. $I_{P h}$ : photo-current

- (A); generated by the photoelectric effect,

- $\quad I_{D}$ : Diode current (A).

$$
I P h=I \mathrm{sc}+K \mathrm{i}(T-T r) \frac{\mathrm{G}}{\mathrm{Gnom}}
$$

Where: Isc: short circuit current (A), Ki: short circuit current of a cell at (STC) standard test condition $25^{\circ} \mathrm{C}$ and $1000 \mathrm{~W} / \mathrm{m}^{2}$, T: operating temperature $(\mathrm{K})$, Tr: reference temperature of the PV cell $(298.15 \mathrm{~K})$, G: solar radiation in $\mathrm{W} / \mathrm{m}^{2}, \mathrm{G}_{\text {nom }}$ : nominal solar radiation $1000 \mathrm{~W} / \mathrm{m}^{2}$, in $(2)$ shows the dependence of the voltage and current of the solar cell on radiation level, temperature, and their changes.

$$
\begin{aligned}
& I o=\operatorname{Irs}\left[\frac{T}{T \mathrm{r}}\right]^{3} \exp \frac{q \times E g o}{A K}\left(\frac{1}{T r}-\frac{1}{T}\right) \\
& \text { Irs }=\text { Iscr } / \exp \left(\frac{\mathrm{q} \text { Voc }}{\text { Ns KA T }}\right)-1
\end{aligned}
$$

Where: -

- Io : Reverse saturation current.

- Irs : cell reverse saturation current at $\mathrm{T} \mathrm{r}$.

- Q : the charge of the electron is equal to $1.6 \times 10^{-19}$ coulomb.

- Ego : bandgap energy of the semiconductor $=1.1 \mathrm{e} \mathrm{V}$.

- A : the ideality factor of the diode, $K$ : Boltzmann's constant equal $1.3805 \times 10^{-23} \mathrm{~J} / \mathrm{k}$.

- Voc : open circuit voltage.

- $\quad N \quad s$ : number of cells connected in series.

Now, the output current of the PV cell is in the following equation.

$$
\mathrm{Ipv}=\mathrm{Iph}-\mathrm{Io}\left[\exp \frac{q \mathrm{Vpv}+\mathrm{Ipv} \times \mathrm{Rs}}{N s A K T}-1\right]+I s h
$$

Where

$$
\mathrm{Ish}=\frac{\mathrm{Vpv}+\mathrm{IPV} \mathrm{Rs}}{\mathrm{Rsh}}
$$

and Rs: series resistance $(\Omega)$, Rsh: shunt resistance $(\Omega), \mathrm{V}_{\mathrm{PV}}$ : output voltage from PV panel.

A PV array can be defined as a set of photovoltaic panels that are connected in series and parallel to obtain specific electrical energy that is practically used to power the loads [9], [13]. In (7) represents the relationship between I-V in the PV array.

$$
\mathrm{Ipv}=\mathrm{N} P \times \mathrm{I} P h-\mathrm{N} P \times \mathrm{I} o\left\{\exp \left[\frac{\left(\mathrm{q} \mathrm{VPV}+\frac{\mathrm{Ns}}{\mathrm{Np}} \mathrm{IPV} \mathrm{Rs}\right)}{\mathrm{Ns} \mathrm{AKT}}\right]\right\}-1+\frac{\mathrm{V} \frac{\mathrm{Ns}}{\mathrm{Np}}+\mathrm{IPV} \mathrm{Rs}}{\mathrm{Rsh}}
$$

Where: $\mathrm{N}_{\mathrm{P}}$ : number of PV modules connected in parallel, $\mathrm{N} s$ : number of PV modules connected in series.

\subsection{Boost converter}

The boost converter is called a step-up converter because the output voltage is greater than the input voltage. Figure 3 shows the structure of the boost converter, which consists of two semiconductors (diode and MOSFET), and the inductor, which is the power storage source in addition to the capacitance such as the filter, load impedance, and DC voltage source (PV array or battery).

MOSFET is used as a trigger switch in the circuit, and the boost switch operates in two modes. The first is when the switch is closed in the ON position, the current is stored in the inductor for a certain period and the diode prevents the current from flowing. With the load current remaining constant due to capacitor discharge. In the second position, when the switch is opened, current flows through the inductor and diode, and the capacitor is charged and from there to the load while the load current also remains constant, the job of the boost converter is to boost and regulate the photovoltaic array voltage, as well as control the duty cycle of the DC-DC converter using MPPT, before sending power to the inverter via the DC-link [14], [15]. Using Faraday's law, the relationship between the output and input voltage of the boost converter can be found as shown [16]. Where: Vs: input voltage, Vo: output voltage of DC-DC boost converter, D: duty cycle.

$$
\text { Vs. DT=(Vo-Vs) (1-D) T }
$$




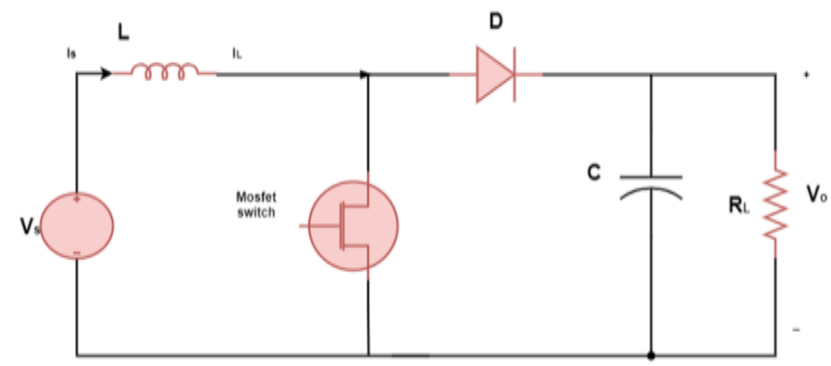

Figure 3. Circuit diagram of the boost converter

\subsection{Incremental conductance algorithm (INC)}

In Figure 4 represents a flowchart of the INC algorithm, features of this algorithm include the speed of processing steady-state errors, rapid response to variable solar radiation, as well as the speed of convergence, as it combines accuracy and speed. The maximum power point in the PV matrix is traced from the derivation of the relationship $\mathrm{P}^{*} \mathrm{~V}$ concerning voltage or current. MPP can be calculated using the dp/dv and $-\mathrm{I} / \mathrm{v}$ relationship and as shown by the following derivation.

$$
\begin{aligned}
& P=V \times I \\
& \frac{d p}{d v}=I+V \cdot \frac{d I}{d v} \\
& \text { or } \frac{d p}{d I}=V+I \cdot \frac{d v}{d I}
\end{aligned}
$$

From the calculation $\Delta I$ and $\Delta V$ to depend on the values $\mathrm{I}$ and $\mathrm{V}$, the MPP values can be inferred from the expressions; $\frac{\Delta \boldsymbol{I}}{\Delta \boldsymbol{V}}>\frac{-\mathbf{I}}{\mathbf{V}}$ The operating point is to the left of MPP, $\frac{\Delta \mathbf{I}}{\Delta \mathbf{V}}=\frac{-\mathbf{I}}{\mathbf{V}}$ The operating point is exactly at MPP, $\frac{\Delta \mathbf{I}}{\Delta \mathbf{V}}<\frac{-\mathbf{I}}{\mathbf{V}}$ The operating point is to the right of MPP According to these comparisons, the algorithm increases or decreases the voltage in the PV array [17], [18].

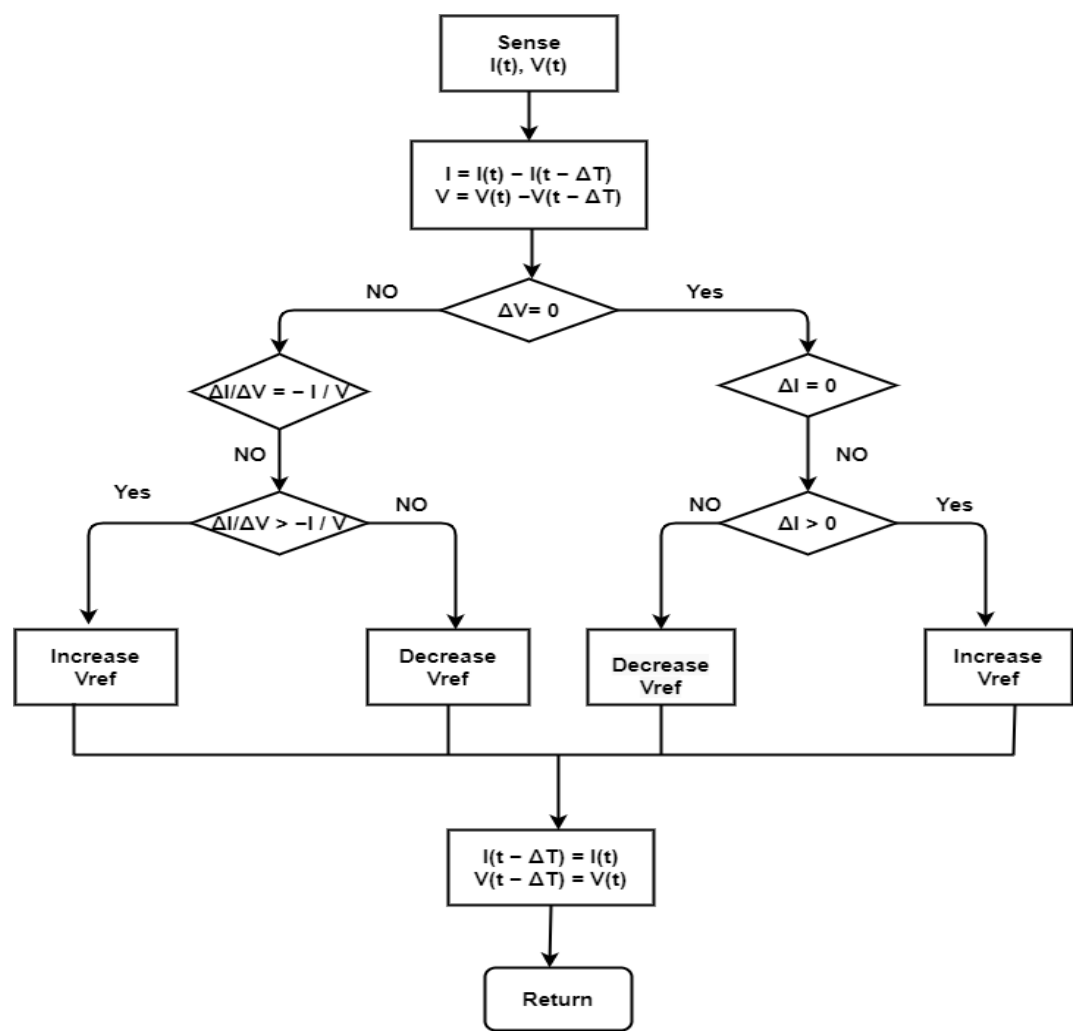

Figure 4. Flowchart of INC algorithm 


\subsection{Cascaded H-bridge inverter}

Cascaded H-bridges are several single-phase inverters or called H-bridge inverter connected in series, eacH-bridge consists of an independent DC source in addition to switches, as shown in Figure 5 This inverter generates a sinusoidal output voltage as each H-bridge provides three levels (zero, positive output voltage, and negative output voltage). The total output voltage is the sum of all the voltages produced by the connected $\mathrm{H}$-bridge cells in the chain. Where if the number of $\mathrm{H}$-bridge cells is $\mathrm{M}$ the total output voltage equal to $(2 \mathrm{M}+1)$. Little harmonic distortion in the output voltage, a higher voltage level, operating at all basic and high switching frequencies, little distortion in the input current with easy storage and packing, and less stress due to the common mode of the voltage are the main benefits of this inverter. As a result, it is preferable to use it over a two-level three-phase inverter [19]-[21].

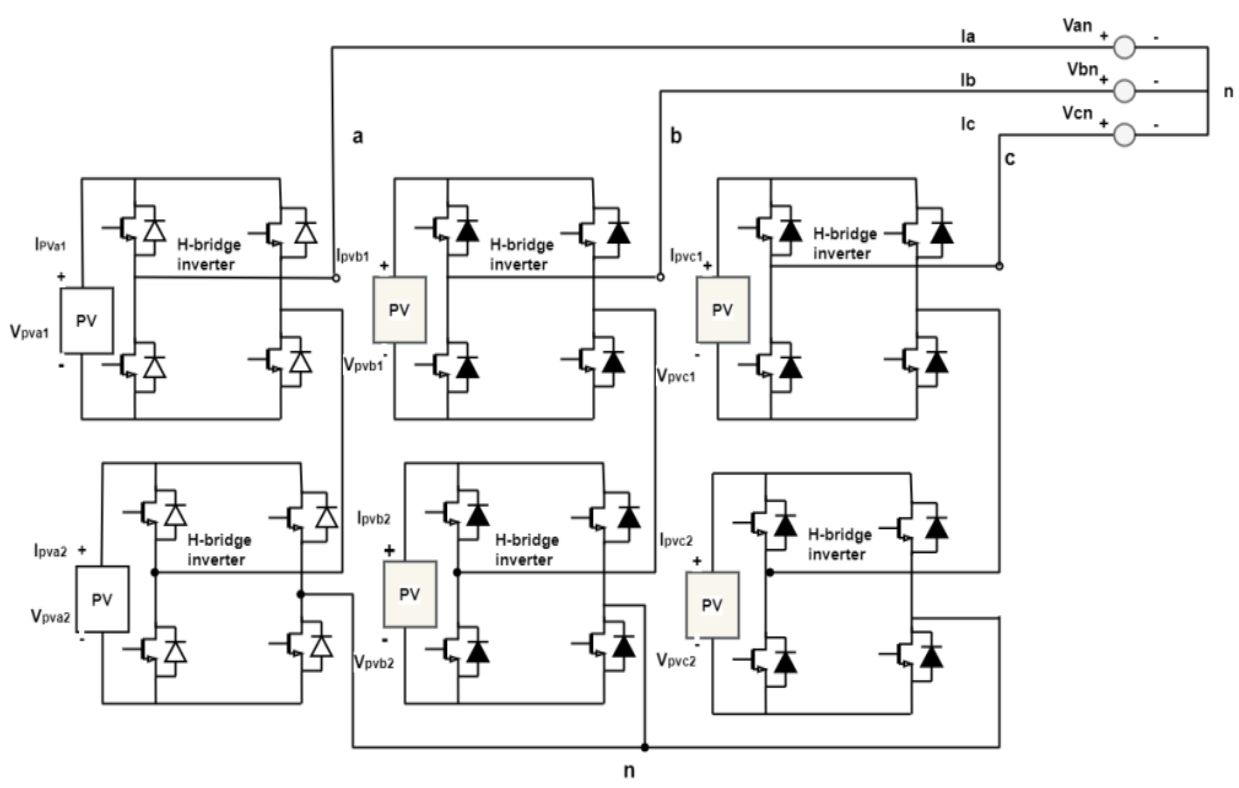

Figure 5. Topology of the modular cascaded H-bridge multilevel inverter for a three-phase grid-connected PV system

\section{CONTROL SCHEME}

One of the most important problems facing the PV system is the mismatch of the PV panels due to the uneven radiation and temperature changes in addition to the lifetime of the solar panels, which means that the MPP is different for each PV model. This reduces the efficiency of the photovoltaic system and the occurrence of problems in the three-phase system at each stage due to the lack of current balance in the grid, so there must be an MPPT for each PV array independently, control and synchronization between microgrid and utility grid, the suggested control approach is clever and compatible with the grid's AC Microgrid connected mode, as it monitors both the DC MPPT and the inverter output AC power [7], [22]. The control process consists of two closed loops, an inner control loop that regulates the current and an external control loop that controls the DC voltage regulation, maintains a constant DC link voltage, and produces signals to the inner control loop as a reference for the current. Changes in conditions affecting the PV array (radiation and temperature) result in a difference in the power produced from it which reaches the utility grid via the DC link. Therefore, the power produced does not match the power that reaches the utility grid, hence the voltage control unit provides a match between the power produced from the PV array and the power delivered to the utility grid by changing the active power of the reference current [22], [23]. The inner control unit (current) can be designed with different frames of reference which are synchronous (dq), fixed frames $(\alpha \beta)$, and natural frames $(a b c)$. It should be capable of harmonic compensation, grid synchronization, active and reactive power control with a fast dynamic response. Since the inverter used is three-phase multilevel, a combination of variable AC signals is used, namely, grid current ( $\left.\mathrm{I}_{\text {abc }}\right)$ and grid voltage $\left(\mathrm{V}_{\text {abc }}\right)$, as well as converting these variable quantities from natural frame (abc) to synchronous frame (dq). Therefore, Clark or Park transformations are required to be used for this purpose, depending on the phase-locked loop (PLL) to estimate the synchronization angle. The control unit (dq) independently controls the active and reactive power by component current (d) for active power and component current (q) for reactive power, to get the unit power factor, component (q) is controlled and made equal to zero and thus the control process becomes 
easier after the disengagement between the two components ( $\mathrm{P}$ and $\mathrm{Q}$ ) and relying on the proportional integration controller PI because of its good advantages in organizing quantities and reducing steady-state error [24]-[26]. The scheme shown in Figure 6 represents the MPPT single control and control circuit for the proposed system. Park transformation in (13) and (14) are applied to convert voltage and current from nature frames into a synchronous reference frame (dq) [27].

$$
\begin{aligned}
& {\left[\begin{array}{l}
V d \\
V q
\end{array}\right]=\sqrt{\frac{2}{3}}\left[\begin{array}{lll}
\sin (w t) & \sin \left(w t-\frac{2 \pi}{3}\right) & \sin \left(w t+\frac{2 \pi}{3}\right) \\
\cos (w t) & \cos \left(w t-\frac{2 \pi}{3}\right) & \cos \left(w t+\frac{2 \pi}{3}\right)
\end{array}\right]} \\
& {\left[\begin{array}{l}
I d \\
I q
\end{array}\right]=\sqrt{\frac{2}{3}}\left[\begin{array}{lll}
\sin (w t) & \sin \left(w t-\frac{2 \pi}{3}\right) & \sin \left(w t+\frac{2 \pi}{3}\right) \\
\cos (w t) & \cos \left(w t-\frac{2 \pi}{3}\right) & \sin \left(w t+\frac{2 \pi}{3}\right)
\end{array}\right]\left[\begin{array}{l}
I a \\
I b \\
I c
\end{array}\right]}
\end{aligned}
$$

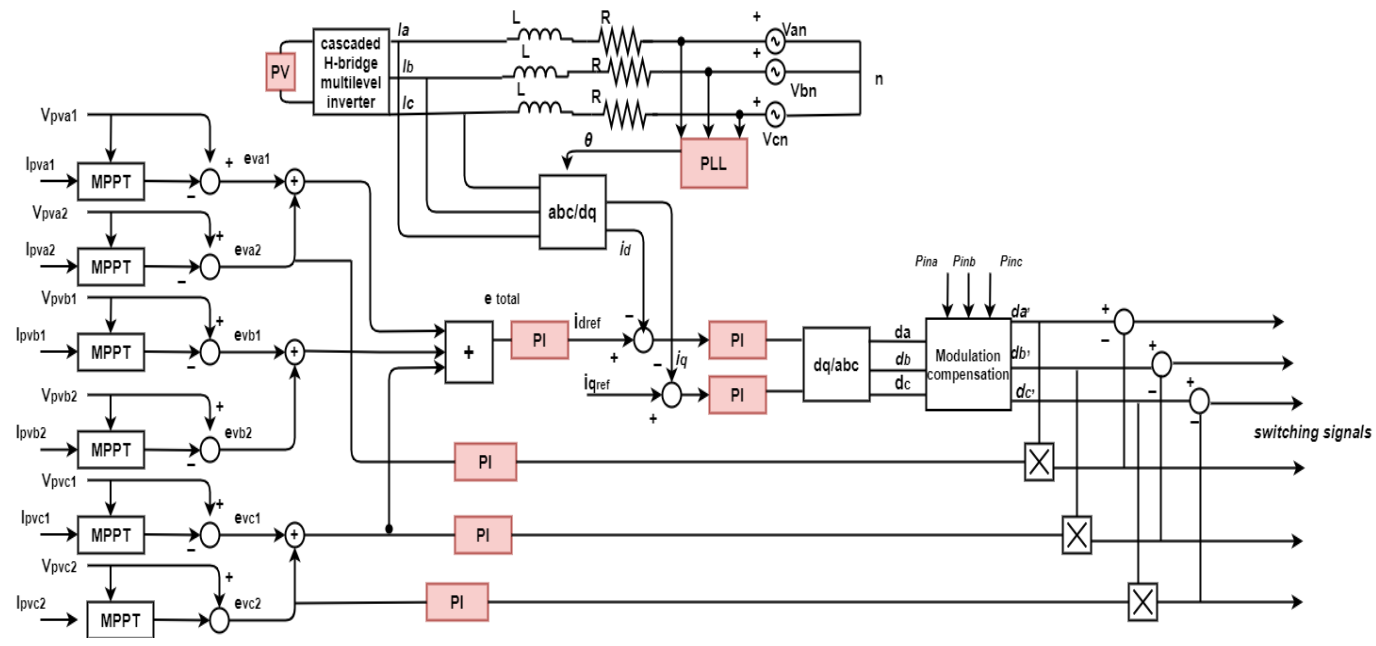

Figure 6. Control scheme for three-phase five-level cascaded H-bridge multilevel inverter

\section{SIMULATION RESULTS}

The cascade multilevel grid-connected inverter simulation was done using the Matlab/Simulink platform. Via an inductor filter and interface transformer, the inverter is coupled to the grid. Table 1 lists the parameters of the PV array. For both irradiation and temperature fluctuations MPP set-point monitoring, detailed simulation investigations were conducted to objectively analyze the performances. For profiles where differences in MPP setpoint monitoring are such that the full range of irradiation and temperature values are used, a good controller is needed. In this section, the simulation results are carried out with two scenarios is being as:

Table 1. The electrical parameters of the PV panel

\begin{tabular}{lc}
\hline \multicolumn{1}{c}{ Parameters } & Values \\
\hline Maximum power (Pmax) & $305 \mathrm{w}$ \\
Rated Voltage (Vmp) & $54.7 \mathrm{v}$ \\
Rated Current (Imp) & $5.58 \mathrm{~A}$ \\
Open Circuit Voltage (Voc) & $64.2 \mathrm{v}$ \\
Short Circuit Current (Isc) & $5.96 \mathrm{~A}$ \\
Number of cells in the panel & 96 \\
\hline
\end{tabular}

\subsection{Scenario I: under standard test condition (STC) $\left(1000 \mathrm{~W} / \mathrm{m}^{2}, 25^{\circ} \mathrm{C}\right)$}

The responses of the PV system for one group are listed in the following figures, as the number of panels used: 54 panels, two panels in series, and 28 panels in parallel, and the output voltage of one PV array is 109.4 volts as in Figure 7 (a), the output current of the PV group is 156.24 A, as shown in Figure 7 (b) and the photovoltaic power output is approximately $17 \mathrm{KW}$, as shown in Figure 7 (c). Under standard irradiance conditions of $1000 \mathrm{~W} / \mathrm{m}^{2}$ and a temperature of $25^{\circ} \mathrm{C}$. Single-phase DC voltage response, Figure 8 (a) shows output DC voltage of two PV groups of approximately 218.5 V. Figure 8 (b) also shows the VDC output at a 
DC link of approximately 500 V. Waveforms of AC load side, Figure 9 (a) shows the output voltage of five CHB levels, Figures 9 (b)-(d) show the output voltage, current, and power of the AC bus.

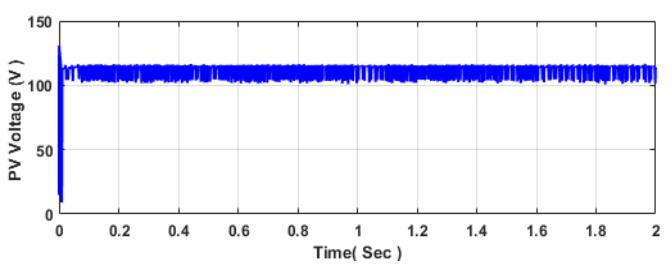

(a)

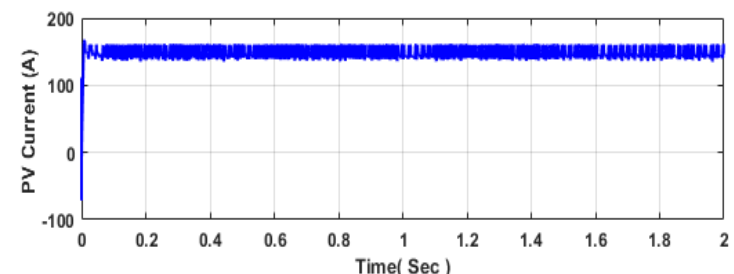

(b)

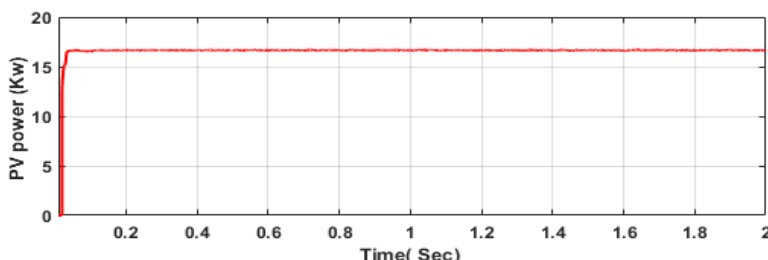

(c)

Figure 7. Responses of PV system for one group, (a) output voltage of PV array, (b) output current of PV array, (c) PV output power

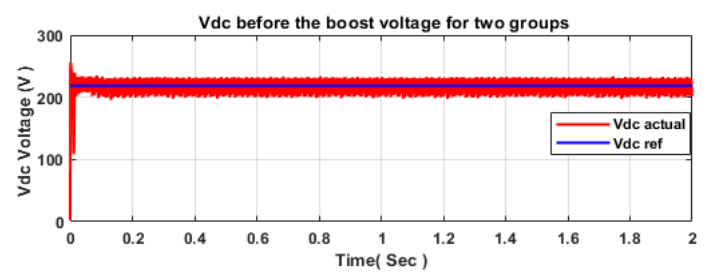

(a)

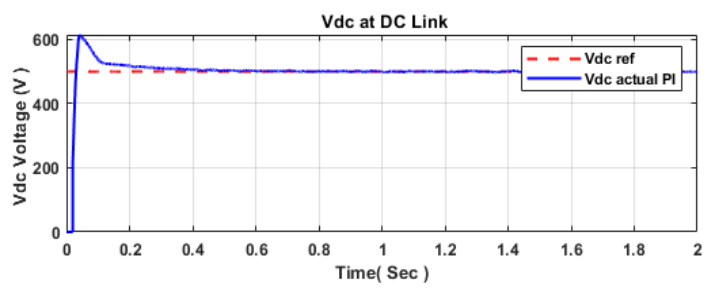

(b)

Figure 8. Response of DC voltage for single-phase, (a) output DC voltage of two PV groups, (b) output $\mathrm{V}_{\mathrm{DC}}$ at DC link

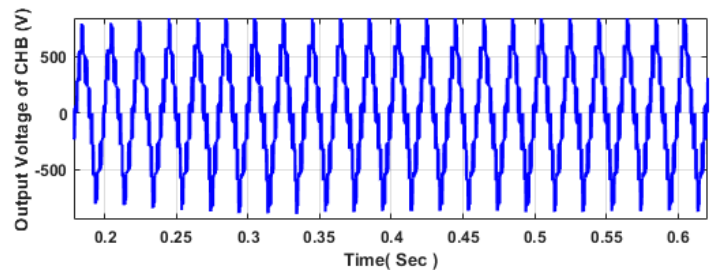

(a)

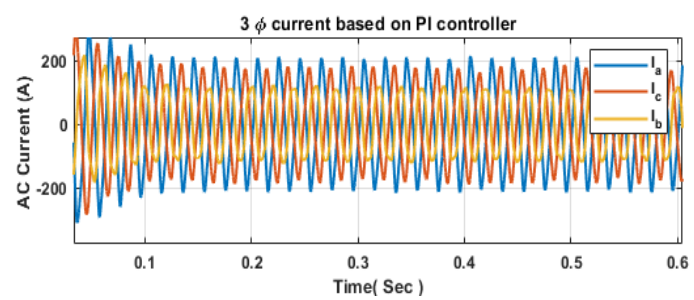

(c)

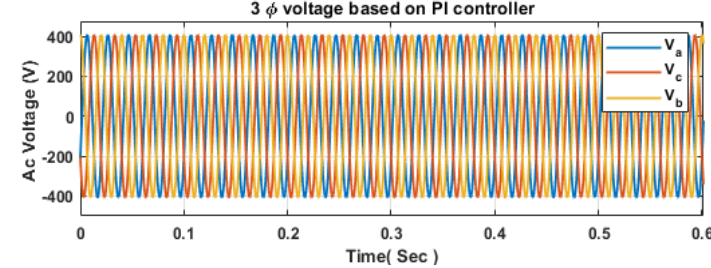

(b)

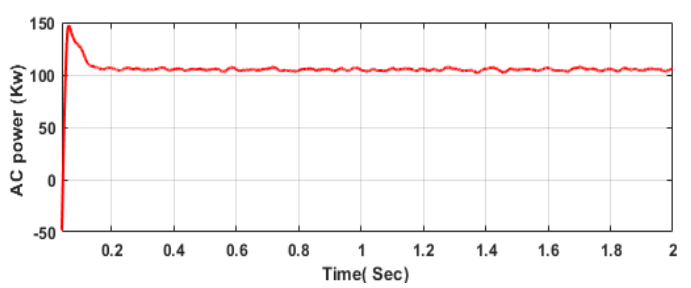

(d)

Figure 9. Waveforms of AC load side, (a) output voltage of five-level CHB, (b) output voltage of AC bus, (c) output current of AC bus, (d) output power of AC bus 


\subsection{Scenario II: under partial shading conditions $\left(500 \mathrm{~W} / \mathrm{m}^{2}, 32^{\circ} \mathrm{C}\right)$}

There are two periodic in the profile used for this test case. For the first periodic $(\mathrm{t}=0 \mathrm{~s}-1.2 \mathrm{~s})$, the irradiation is reduced to $500 \mathrm{~W} / \mathrm{m}^{2}$, and the temperature is maintained at STC $\left(25 \mathrm{C}^{\circ}\right)$. While in the second periodic $(\mathrm{t}=1.2 \mathrm{~s}-2 \mathrm{~s})$, the irradiation level returns to the maximum irradiation of $1000 \mathrm{~W} / \mathrm{m}^{2}$, and the temperature is increased to $32 \mathrm{C}$, as shown in Figures 10 (a)-(c), 11 (a), (b), and 12 (a)-(d). The output voltage and current injected into the grid by the proposed converter during controlled operation are shown in Figure 12 (a). The proposed converter, as can be seen in this diagram, has a five-level output voltage waveform that is very stable. While, the output voltage of PV groups and output power of AC side load is very tracking to the maximum power desired at $\left(500 \mathrm{~W} / \mathrm{m}^{2}, 25^{\circ} \mathrm{C}\right)$, as well as in $\left(500 \mathrm{~W} / \mathrm{m}^{2}, 32 \mathrm{C}\right)$ as shown in Figures 10 (c) and 12 (d). The PV voltage of one group, the DC link voltage, and the AC voltage waveform have been depicted in Figures 10 (a), 11 (a), (b), and 12 (b). It obvious from these figures all voltages have remained constant, which implies the system is very stable and rejected the disturbances.

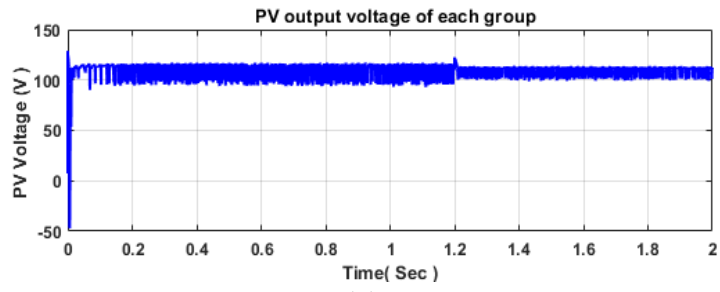

(a)

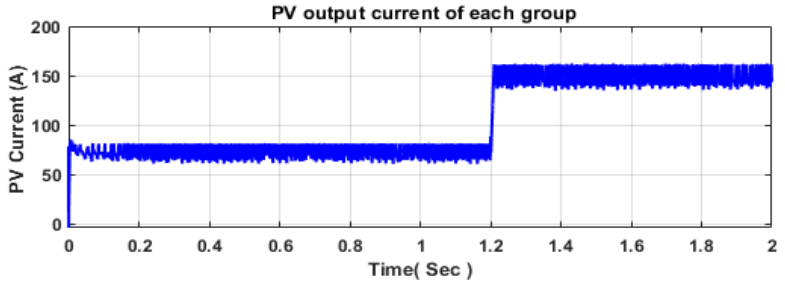

(b)

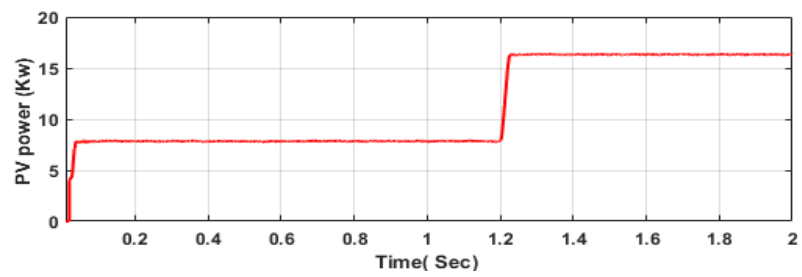

(c)

Figure 10. Responses of PV system for one group, (a) output voltage of PV array, (b) output current of PV array, (c) PV output power. under $500 \mathrm{w} / \mathrm{m}^{2}$ and $25^{\circ} \mathrm{C}$ condition

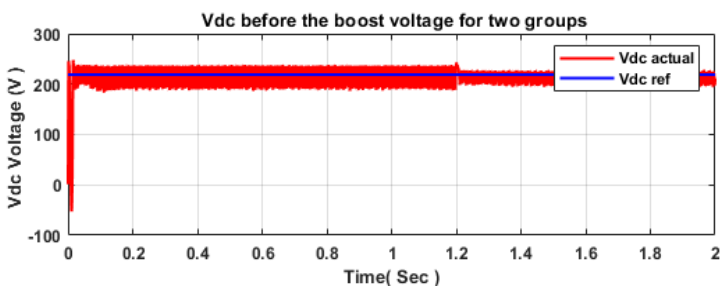

(a)

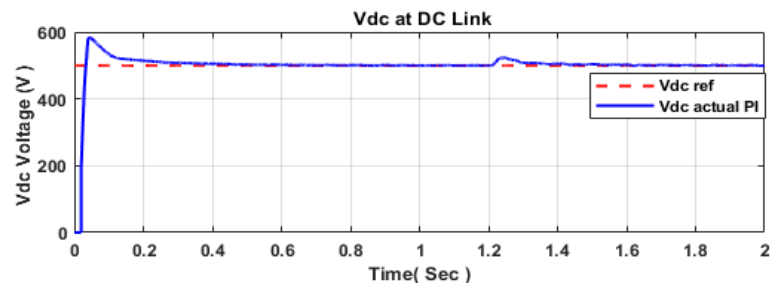

(b)

Figure 11. Response of DC voltage for single-phase, (a) output DC voltage of two PV groups, (b) output $\mathrm{V}_{\mathrm{DC}}$ at DC link

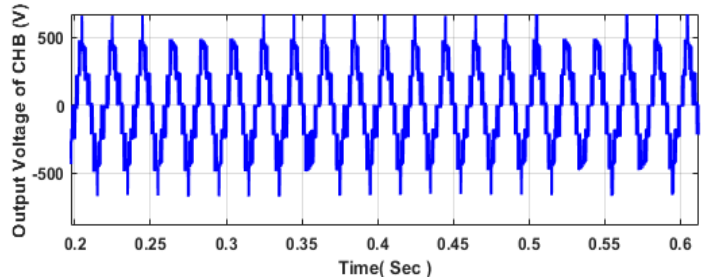

(a)

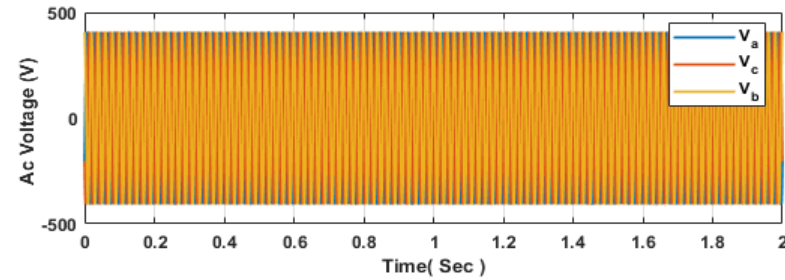

(b)

Figure 12. Waveforms of AC load side, (a) output voltage of five-level CHB, (b) output voltage of AC bus 


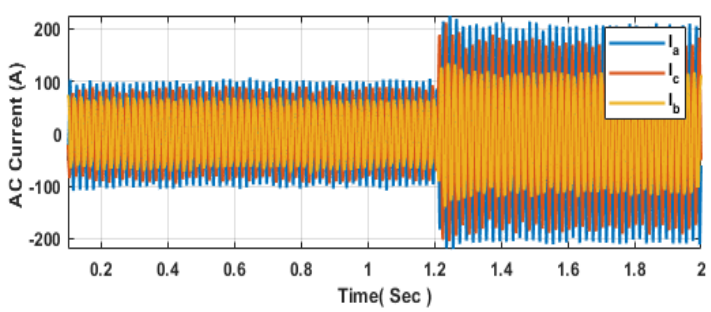

(c)

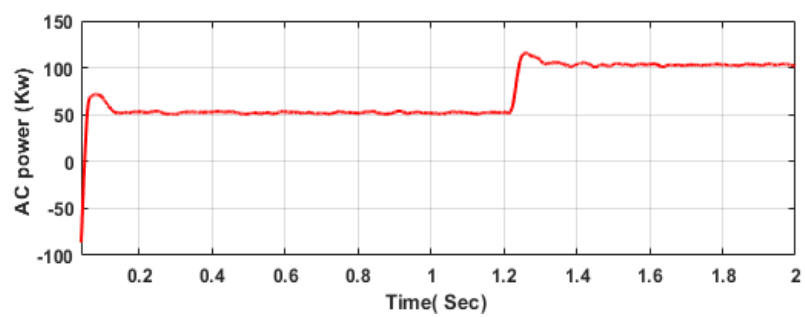

(d)

Figure 12. Waveforms of AC load side, (c) output current of AC bus, (d) output power of AC bus. Under 500 $\mathrm{w} / \mathrm{m}^{2}$ and $25^{\circ} \mathrm{C}$ (continue)

\section{CONCLUSION}

This article presents a modified connected usng five level cascade $\mathrm{H}$ brdge inverter wth six PV group system to reduce the effect of mismatch power and minmize the shading impact by separate each PV group with DC-DC converter and MPPT to get the maximum output power of six PV group to achieve to the design power which is $100 \mathrm{Kw}$. The results demonstrated the importance of the multilevel inverter in output a stable and pure AC voltage wave, as well as the effectiveness of the proposed control method in addressing the issue of photovoltaic panel mismatch and reducing wastage, thus improving the efficiency and stability of the photovoltaic system.

\section{REFERENCES}

[1] P. Ray and M. Biswal, "Lecture notes in electrical engineering 625 microgrid: operation, control, monitoring, and protection," Springer, 2020. [Online]. [Available]: https://www.springer.com/gp/book/9789811517808\#aboutAuthors.

[2] P. K. Panda, A. Sahoo, A. Samal, D. P. Mishra, and S. Reddy, "Voltage control of AC hybrid microgrid," International Journal of Power Electronics and Drive System (IJPEDS), vol. 12, no. 2, pp. 793-802, June 2021, doi: 10.11591/ijpeds.v12.i2.pp793-802.

[3] S. Bayhan, H. Abu-Rub, J. I. Leon, S. Vazquez, and L. G. Franquelo, "Power electronic converters and control techniques in AC microgrids," IECON 2017-43rd Annual Conference of the IEEE Industrial Electronics Society, 2017, pp. 6179-6186, doi: 10.1109/IECON.2017.8217073.

[4] G. Jayaraju, and G. S. Rao, "Intelligent controller based power quality improvement of microgrid integration of photovoltaic power system using new cascade multilevel inverter," International Journal of Electrical and Computer Engineering (IJECE), vol. 9, no. 3, pp. 1514-1523, June 2019, doi: 10.11591/ijece.v9i3.pp1514-1523.

[5] A. Krishna R, and L. P. Suresh, "A brief review on multi level inverter topologies," 2016 International Conference on Circuit, Power and Computing Technologies (ICCPCT), 2016, pp. 1-6, doi: 10.1109/ICCPCT.2016.7530373.

[6] I. H. Shanono, N. R. H. Abdullah, and A. Muhammad, "A survey of multilevel voltage source inverter topologies, controls, and applications," International Journal of Power Electronics and Drive Systems (IJPEDS), vol. 9, no. 3, pp. 1186-1201, September 2018, doi: 10.11591/ijpeds.v9.i3.pp1186-1201.

[7] Er. M. Sandhu, and T. Thakur, "Multilevel inverters literature survey-topologies, control techniques \& applications of renewable energy sources-grid integration," International Journal of Engineering Research and Applications, vol. 4, no. 3, pp. 644-652, March 2014.

[8] S. S. Katkamwar, and V. R. Doifode, "Cascaded H-bridge multilevel PV inverter with MPPT for grid connected application,” 2016 International Conference on Energy Efficient Technologies for Sustainability (ICEETS), 2016, pp. 641-646, doi: 10.1109/ICEETS.2016.7583832.

[9] A. Lashab et al., "Cascaded multilevel PV inverter with improved harmonic performance during power imbalance between power cells," in IEEE Transactions on Industry Applications, vol. 56, no. 3, pp. 2788-2798, May-June 2020, doi: 10.1109/TIA.2020.2978164.

[10] T. S. Kishore, S. D. Kaushik, and Y. Venu Madhavi, "Modelling, simulation and analysis of PI and FL controlled microgrid system," 2019 IEEE International Conference on Electrical, Computer and Communication Technologies (ICECCT), 2019, pp. 1-8, doi: 10.1109/ICECCT.2019.8869379.

[11] S. Bouacha, A. H. Arab, N. Belhaouas, S. Semaoui, and M. Haddadi, "Modeling and simulation of 1MW grid connected photovoltaic system," The 2nd International Conference on Power Electronics and their Applications (ICPEA 2015), March 2015.

[12] X. H. Nguyen, and M. P. Nguyen, "Mathematical modeling of photovoltaic cell/module/arrays with tags in Matlab/Simulink," Environmental Systems Research, vol. 4, no. 1, pp. 1-13, 2015, doi: 10.1186/s40068-015-0047-9.

[13] S. Sahbani, H. Mahmoudi, A. Hasnaoui, M. Kchikach, and H. Benchraa, "A novel fast MPPT strategy used for grid-connected residential PV system applied in Morocco," International Journal of Power Electronics and Drive Systems (IJPEDS), vol. 11, no. 2, pp. 942-952, June 2020, doi: 10.11591/ijpeds.v11.i2.pp942-952.

[14] M. Kumar, "Design and simulation of grid connected PV system," ph.D dissertation, Submitted in Partial Fulfillment of Master of Technology in Power System (Electrical Engineering) Department Of Electrical Engineering, 2016. 
[15] R. Nagarajan, J. Chandramohan, and S. Sathishkumar, "Implementation of PI controller for boost converter in PV System," International Journal of Advanced Research in Management, Architecture, Technology and Engineering (IJARMATE), vol. 2, no. 22, pp. 6-10, April, 6-10.

[16] M. H. Rashid, Power Electronics Handbook, Butterworth-Heinemann, 2018.

[17] F. L. Tofoli, D. De C. Pereira, and W. J. de Paula, "Comparative study of maximum power point tracking techniques for photovoltaic systems," International Journal of Photoenergy, vol. 2015, 2015, doi: $10.1155 / 2015 / 812582$.

[18] M. H. Uddin, M. A. Baig, and M. Ali, "Comparision of 'perturb \& observe' and 'incremental conductance', maximum power point tracking algorithms on real environmental conditions," 2016 Int. Conf. on Computing, Electronic and Electrical Engineering, ICE Cube 2016-Proceedings, 2016, doi: 10.1109/ICECUBE.2016.7495244

[19] B. Singh, B. Verma, and P. K. Padhy, "Study of P\&O and INC PV MPPT techniques for different environment conditions," 2018 2nd IEEE International Conference on Power Electronics, Intelligent Control and Energy Systems (ICPEICES), 2018, pp. 165-169, doi: 10.1109/ICPEICES.2018.8897479.

[20] R. Mahalakshmi, and K. C. S. Thampatty, "Grid connected multilevel inverter for renewable energy applications," Procedia Technology, vol. 21, pp. 636-642, 2015, doi: 10.1016/j.protcy.2015.10.076.

[21] L. H. Pratomo, and S. Riyadi, "Design and implementation of a single-phase five-level inverter using a DC source with voltage balancer on capacitor," International Journal of Power Electronics and Drive System (IJPEDS), vol. 12, no. 2, pp. 902-912, June 2021, doi: 10.11591/ijpeds.v12.i2.pp902-912.

[22] K. A. K. Niazi, Y. Yang, and D. Sera, "Review of mismatch mitigation techniques for PV modules. IET Renewable Power Generation," IET Renewable Power Generation, vol. 13, no. 12, pp. 2035-2050, 2019, doi: 10.1049/ietrpg.2019.0153.

[23] M. N. Mohsin, "Design of a grid-connected photovoltaic power electronic converter," Master's thesis, UiT Norges arktiske universitet, vol. 1, no. 1, pp. 1-90, 2017. [Online]. [Available]: http://www.bioone.org/doi/abs/10.3159/10RA-011.1.

[24] D. Y. Mahmood, A. H. Numan, and J. K. Ateih, "Simple and efficient control method for battery charging in high penetration photovoltaic array," International Research Journal of Engineering and Technology (IRJET), vol. 6, no. 5, pp. 1813-1819, May 2019.

[25] M. R. J. Devi, and M. S. S. Kadam, "Synchronization of three phase inverter with electrical grid," International Journal of Engineering Research, vol. 4, no. 05, pp. 1024-1031, 2015, doi: 10.17577/ijertv4is050938.

[26] S. M. Kaviri, M. Pahlevani, P. Jain, and A. Bakhshai, "A review of AC microgrid control methods," 2017 IEEE 8th International Symposium on Power Electronics for Distributed Generation Systems (PEDG), 2017, pp. 1-8, doi: 10.1109/PEDG.2017.7972498.

[27] G. J. May, A. Davidson, and B. Monahov, "Lead batteries for utility energy storage: A review," Journal of Energy Storage, vol. 15, pp. 145-157, February 2018, doi: 10.1016/j.est.2017.11.008.

\section{BIOGRAPHIES OF AUTHORS}

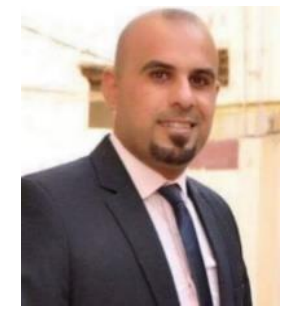

Marwan Saded Ahmed, is an M.Sc. degree student in the research level at Electrical Engineering Department, University of Technology, Baghdad, Iraq, and complete a B.Sc. degree in 2009 in the Electrical Engineering Department, University of Dyala, Dyala, Iraq. Mr. Marwan is interested in Power Electronic Converters, PV Systems, Microgrid systems, and Storage Energy Systems. Email: eee.19.09@grad.uotechnology.edu.iq

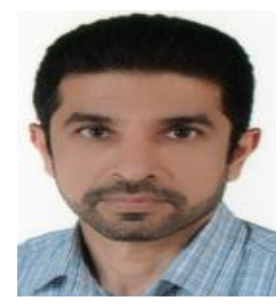

Ali Hussein Numan received the BSc, M.Sc, and Ph.D. in Electrical Engineering from the University of Technology, in 1999, 2003, and 2009, respectively. Currently, he is an Associate Professor of Electrical Engineering in the Electromechanical Engineering Department of the University of Technology (UoT). He has co-authored the textbook Small and Special Electric Motor and Their Control Technique, 2016, and published 37 journals and conferences papers. His research interests include power electronics, variable speed drives, renewable energy, and modeling and simulation. Email: ali.h.numan@uotechnology.edu.iq

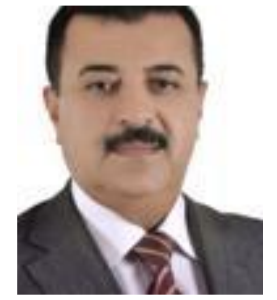

Dhari Yousif. Mahmood is a. Prof at the Department of Electrical Engineering at the University of Technology- Baghdad-Iraq. He was awarded his M.Sc and Ph.D. in Electrical Power Engineering from Sant.Peterburg Polytechnical Institute-Russa in 1986 and 1990 respectively. His BSc degree was received in 1981 from the University of Baghdad-Collage of Engineering-Iraq. He works in the field of renewable energy and power system analysis. He supervises a large number of postgraduate students in both masters and Ph.D. degrees. Email: dhari.y.mahmood@uotechnology.edu.iq 